\title{
Listing and Value: A Cross-Country Analysis in the Energy Sector
}

\author{
Anna Paola Micheli ${ }^{1}$, Carmelo Intrisano ${ }^{1}, \&$ Anna Maria Calce ${ }^{1}$ \\ ${ }^{1}$ University of Cassino and Southern Lazio, Italy \\ Correspondence: Anna Maria Calce, University of Cassino and Southern Lazio, Italy
}

Received: November 4, 2021

Accepted: November 27, 2021

Online Published: November 29, 2021

doi:10.5539/ibr.v14n12p147

URL: https://doi.org/10.5539/ibr.v14n12p147

\begin{abstract}
The study aims to fill a gap in the literature on the impact of listing on value. Most of the relevant literature analyzes the impact of listing by focusing on the financial performance of companies. The innovative aspect of this study lies in considering value as a combination of return on equity and risk profile, the latter reflected in the cost of capital. So, in this analysis value is ascertained with the ROE-ke measure. We compare listed companies vis-à-vis their unlisted peers in the energy sector. Data are extracted from Amadeus and covers the period from 2015 to 2017. The empirical investigation considers the following areas: profitability (ROE); cost of equity (ke) and value (ROE-ke). We observe statistically significant differences between listed and unlisted companies. In particular, listed companies show lower cost of equity but they also have lower profitability than unlisted companies. Furthermore, results highlight that listing has a negative impact on shareholder value: listed companies have negative ROE-ke or they register less ROE-ke if compared with unlisted peers. This research has several limitations, for example, having considered a relatively short period of time. Future developments of this work may overcome some limitations by taking into account more recent years and using additional variables such as governance, financial structure, operations in the renewable energy sector, size.
\end{abstract}

Keywords: cost of equity, energy sector, listing, profitability, value
Abbreviations
ROE Return on equity
$\mathrm{k}_{\mathrm{e}} \quad$ Cost of equity
$r_{f} \quad$ Risk-free rate
MRP Market risk premium

\section{Introduction}

The necessity to deal with listing versus non-listing arises in relation to the need for growth and financing of new investment projects through risk capital. Although a company can finance new projects by resorting to debt capital, it is likely to imagine that once a certain level of leverage is exceeded, the company must necessarily raise risk capital to grow. The entry into a capital market therefore represents the assumption that leads to study the effects that listing produces in terms of value, considering that the existing contributions in literature mainly study its impact on financial performance.

Corporate growth is a strategy that requires equity, i.e. patient capital to be allocated to long-term investments. Business growth strategies are more easily pursued by companies that decide to resort to the capital market because in this case the value of the company is updated in real time thanks to the exchanges involving the share. In general, listed companies, being able to place financial instruments representing debt and risk capital, are more suitable for achieving and maintaining conditions of financial equilibrium, also by diversifying the sources of financing. Furthermore, the improvement in credit standing after the listing leads to lower interest rates and to a reduction in cost of capital. More generally, listed companies can count on a significant improvement in their image, especially towards external stakeholders, and on a more solid relational network that promotes the development of new businesses. Listing determines positive effects for shareholders, including the greater liquidity of their investment and the facilitation of generational turnover. However, listing also has disadvantages. These mostly consist of the costs required to undertake the listing process and of the charges to remain on the market. The amount of these costs is affected by various factors such as the time needed to complete the listing process, the size and methods of placement. Access to the capital market also determines costs to comply with the 
requirement of transparency imposed by staying on the financial markets and related to the redefinition of one's organizational structure.

Much of the literature analyzes the impact of listing by focusing on the financial performance of companies; moreover, the literature is inconclusive with respect to the impacts of listing on performance. A knowledge gap in literature is the impact of listing on value. This research intends to fill this gap: the innovative aspect lies in considering value as a combination of return on equity and risk profile, the latter reflected in the cost of capital. So, in this study value is not considered as financial performance. Therefore, the objective of this paper is to ascertain the value with the ROE- $\mathrm{k}_{\mathrm{e}}$ differential and, through a comparative analysis between listed and unlisted companies, to verify whether listing is able to generate value.

Energy sector is considered in this analysis because of its strategic importance for every national economy. This sector is facing a rapidly changing environment and is now affected by a period of reform and repositioning in production choices, in internal processes, in the identification and articulation of human resources, in the market offer and in the competitive and network ecosystem. We contribute to the debate on value creation in the energy industry by examining the impact of listing on firms in the energy sector in Europe.

\section{Literature}

Value creation, a central theme in Corporate Finance, has captured the attention of numerous scholars over the years, who have explored its determinants from different points of view. Benjamin Graham (1954) used the concept of value as an element to identify listed companies able to create value in a constant way over time. This line of thinking was then shared by Warren Buffet, who identified the quantitative variables capable of generating value. More recently the topic has been the subject of strong interest on the basis of the lines of thought emerging during the 20th century (Kersan-Škabić, 2019). The researches of Damodaran (2012), Bruce Greenwald, Kahn, Sonkin and van Biema (2001) and Fernandez (2007) updated the previous models by evaluating complementary quantitative factors such as credit, risk, financial leverage, cost of capital. Some scholars examined additional factors such as corporate risk, liquidity, and debt (Tiozo \& Leismann, 2019). Finally, academics analyzed the relationship between short-term results and value creation in specific sectors, such as the chemical industry (Lan \& $\mathrm{Li}, 2005$ ), and developed a management expectations model to align expected earnings and creation of value (Skinner \& Sloan, 2002).

Other models focused on the creation of value based on the ability of the firm to offer an extra return to the entire invested capital (Stern, Stewart, \& Chew, 1995). Further research applied the EVA model adapting it to different industrial sectors and markets (Chen \& Qiao, 2008). Other scholars proposed models for identifying value through qualitative variables and behavioral factors such as Whitney and Deming (1996) and (Balafas \& Florackis, 2014). Finally, social responsibility and governance were contrasted with financial performance as an indicator of value creation (Rodriguez-Fernandez, 2016; Mitra, O'Regan, \& Sarpong, 2018).

However, in the literature, there is a knowledge gap relating to the link between listing and value (Lafont Romero, Palacios, \& Ruiz, 2020). The topic of listing is mainly analyzed by focusing on the relationships between financial performance and listing as well as on the effects produced by the listing in terms of cash flow and balance sheet indicators, often comparing the performance in the pre and post-listing period. Other contributions analyze the listing as an opportunity to access new forms of equity, increase transparency by reducing information asymmetries and consolidate one's image towards stakeholders.

Regarding the first aspect, it is known that companies select loans based on the advantages and disadvantages that the composition of the financial structure produces on maximizing value, in line with their financial needs. Several authors analyzed the financial structure focusing on the raising of equity from the capital market and on the consequences that the opening to the financial market produces for the ownership structure. Equity has the advantage for the company of having capital without a predefined repayment date: the shareholders are remunerated on a residual basis, compatible with the cash flows produced by the management (Ou \& Haynes, 2006). In the context of risk capital, it is necessary to choose between the contribution of the owner, self-financing, and recourse to the stock market. The first two are the methods most consistent with the logic of maximizing shareholder value considering that the issue of additional shares to meet the financial needs of the company, contrary to the other two methods of financing, involves a dilution of ownership and control. To maintain corporate control, owners may prefer loans in the form of debt rather than increasing share capital and obtaining additional resources as equity. Concerning debt capital, the choice between the short and medium-long term is influenced by the benefits and disadvantages associated with the different types of loans (García - Teruel \& Martínez - Solano, 2007; Jun \& Jen, 2003). Some authors identified in their studies other variables capable of influencing financial structure decisions and, therefore, also the decision to go public: these include the life cycle phase of the company, 
size, profitability, the availability of collateral, ownership structure, industry sector, and geographical location (Guiso, 2003; Caselli, 2003; Corigliano, 2001; Worthington, 2013; Hutchinson \& Ray, 1983; Keown Scott, Martin, \& Petty 1985; Bates \& Hally, 1982; Osteryoung, 1997; McLaney, 2009). The going public decision is also perceived as a tool to reduce the problem of information asymmetry: not all the information available to the company is shared with the lenders. The latter compared to the company to be financed can count on a qualitatively and quantitatively lower availability of information. Companies tend to select the information to be transferred to increase the chances of obtaining financing. In this context, the use of external financing produces a signaling effect on the market (Ross, 1977; Leland \& Pyle, 1977; Myers \& Majluf, 1984). External lenders are unable to determine exactly the value of the securities issued by companies to carry out new projects and investments. Therefore, they would conclude that the managers of the company manage and decide in the interest of the current shareholders. A possible share issue would therefore be perceived by the market as an attempt to transfer value from new shareholders to current ones with the consequence of placing the equity at a price lower than the market price. Hence the tendency of managers to avoid or limit the use of the equity of external origin, giving priority to other forms of financing deemed most suitable for protecting shareholder value. Consistent with the Pecking Order Theory, preference is therefore assigned to self-financing and then to debt (Fama \& Miller, 1972; Jensen \& Meckling, 1976; Myers, 1977). The listing also reduces the information asymmetry that has always characterized the relationship between shareholders and management. Listed companies are subject to market monitoring that involves an increase in transparency and the protection of shareholders. So, it is more difficult for management to carry out acts to the detriment of minority shareholders. The transparency imposed by the market can allow shareholders to verify whether the management's actions are in line with the objectives set or if there is a divergence of interests.

A further area of research concerns the analysis of the effects of listing on corporate performance. In this regard, some authors focus the research on listed companies or on the comparison between these and unlisted companies (Muthoni, Jagongo \& Muniu, 2019; Nhan \& Son, 2017; Hung, Thien \& Liem, 2017; Mayer \& Alexander, 1991; Rondi, Sembenelli, \& Zanetti, 1994; Rijken, Booij, \& Buckley, 1999; Berkovitch, Gesser, \& Sarig, 2004; Abbate \& Sapio, 2015; Akguc, Choi \& Kim, 2015; Schoubben \& Van Hullen, 2008; Xiaoying Xie, 2010; Capasso, Rossi, \& Simonetti, 2005; Aiello \& Silipo, 1997). Others compare performance before and after listing (Mikkelson, Partch, \& Shan, 1997; Nguyen Van Tan \& Trinh Quoc Trung, 2019; Pagano, Panetta, \& Zingales, 1996; Carpenter $\&$ Rondi, 2006). These studies show inconsistent results. Some of them show the superiority of listed companies, while others highlight the opposite.

The analysis of the existent literature allows highlighting the most chosen variables in the studies with a focus on the topic. It should be emphasized that ROE, ROA, ROI, EBITDA margin, Asset turnover, Sales, Reinvestment rate, Current ratio, Liquidity ratio, D/E, Operating performance, Financial charges, Total financial payables, Net capital, Total debts, Net income are among the most used variables. So most studies use purely accounting variables without considering the relationship between profitability and cost of capital as a measure of the value created or destroyed.

In summary, the state of the art shows the absence of a shared opinion about the superiority of listed companies over unlisted companies and also highlights the lack of relevant contributions focused on the search for a relationship between listing and value expressed as a ROE- $\mathrm{k}_{\mathrm{e}}$ differential. Hence, this study aims to contribute to increasing knowledge of the phenomenon given the uncertainty of existing contributions.

\section{Data and Methodology}

To examine the effects of listing and value creation we extracted companies from Amadeus. The data consist of listed and unlisted energy firms in Europe. Specifically, we examine firms from Austria, Belgium, Denmark, Finland, France, Germany, Ireland, Italy, Luxembourg, Netherlands, Norway, Poland, Portugal, United Kingdom, Spain, Sweden, and Switzerland. Firms across these countries contribute to the composition of the Stoxx Europe 600 index: hence, the belief that belonging to the same stock index presupposes elements of affinity between the countries themselves. The sample period is from 2015 to 2017. The analysis is based on data in a panel format. The information available has the characteristics of both cross-sectional data (the variables of several companies are observed for a given year) and time-series data (for all the companies the quantities are measured over the three years).

The research aims to answer the question "Does listing create value in the energy sector?". Consistently with the shareholder approach, the primary variable of interest is the ROE- $\mathrm{k}_{\mathrm{e}}$ differential. We considered it as a value explicative variable, where ROE and $\mathrm{k}_{\mathrm{e}}$ are the benefits and sacrifices of shareholders (Adams \& Thornton, 2009; Arzac, 1986; Magni, 2011). 
The empirical investigation considers the following areas:

- gap analysis of the profitability (ROE) of listed companies and unlisted companies;

- gap analysis of the cost of equity $\left(\mathrm{k}_{\mathrm{e}}\right)$ of listed companies and unlisted companies;

- gap analysis of the value (ROE-ke) of listed companies and unlisted companies.

To improve their statistical significance ROE, $\mathrm{k}_{\mathrm{e}}$ and ROE- $\mathrm{k}_{\mathrm{e}}$ were subjected to the elimination of outliers with identification of the related upper and lower fence parameters. Through the analysis of descriptive statistics, the data were observed in their essential features concerning shape, central tendency, and variability. To verify the existence of significant differences in profitability, cost of equity risk-free, and value, the comparison between the two sets of firms was performed using the t-test.

The cost of equity $\left(\mathrm{k}_{\mathrm{e}}\right.$ ) was calculated through the Capital Asset Pricing Model (CAPM) explained by the following formula:

- $\mathrm{r}_{\mathrm{f}}$ is the risk-free rate;

$$
k e=E\left(r_{i}\right)=r_{f}+\beta_{i} \times M R P
$$

- $\quad \beta_{\mathrm{i}}$ reflects the volatility of generic security $i$ concerning the market portfolio.

- MRP is the Market Risk premium, the excess return of the market portfolio compared to the risk-free rate.

In this study, parameters were estimated as follows:

- The Germany 10 years bond was chosen as a risk-free rate. This is considered non-risky security par excellence in Europe since it has the lowest default risk (Damodaran, 2008). The risk-free rate is calculated as the average of the weekly yields of the Germany 10 years bond over a time horizon of 3 years. Therefore:

- for 2015 the risk-free rate is computed as the average of the weekly returns for the period from 01 January 2012 to 31 December 2014;

- for 2016 the risk-free rate considers the average of the weekly returns for the period from 01 January 2013 to 31 December 2015;

- for 2017 the risk-free rate is calculated as the average of the weekly returns for the period from 01 January 2014 to 31 December 2016.

The values identified are shown below (Table 1):

Table 1. Risk-free rate (2015-2017)

\begin{tabular}{lrrr}
\hline & 2015 & 2016 & 2017 \\
\hline Risk-free rate & $1.47 \%$ & $1.13 \%$ & $0.62 \%$ \\
\hline
\end{tabular}

- $\beta$ was estimated by adopting the historical approach. Using historical returns, this method involves calculating the covariance of the returns of a generic stock with the return of the market index and the variance of the return of the market index. The basic assumption is that the returns recorded in the past will tend to replicate in the future and, therefore, the beta of the security in the future will be aligned with the beta of the past. For this analysis, the calculation of $\beta$ considers the historical returns of 3 years with weekly observations. Empirical evidence shows that the use of observations at high frequencies, such as weekly ones, is to be preferred as on the one hand it allows to reduce the problem known as "noise of the market" (connected to deviations between actual and expected price) typical of daily observations and on the other hand, it allows to compensate for the reduced number of data in the case of recourse to monthly observations (Henry 2008; Henry 2009; Henry \& Street 2014; Duc Hong Vo \& Thach Ngoc Pham 2017; Fernandez 2019). By applying simple linear regression, we proceeded to regress the returns of the stock with the returns of the market index represented by the Stoxx Europe 600. Regression concerns the weekly returns:

- from 01 January 2012 to 31 December 2014 for the beta for 2015;

- from 01 January 2013 to 31 December 2015 for the beta for 2016;

- from 01 January 2014 to 31 December 2016 for the beta for 2017.

The beta of unlisted companies is calculated indirectly. Starting from the levered beta of the listed firms, we proceeded, applying the Hamada formula, to the estimate of the unlevered beta which reflects only the operational risk of each listed company: 


$$
\beta_{u}=\left[\beta_{l} /(1+(1-t) \times D / E)\right]
$$

The industry average unlevered beta was therefore determined, assuming the following values (Table 2):

Table 2. Industry average unlevered beta (2015-2017)

\begin{tabular}{|c|c|c|c|}
\hline & 2015 & 2016 & 2017 \\
\hline $\begin{array}{ll}\text { Industry } & \text { average } \\
\text { unlevered beta }\end{array}$ & 0.228 & 0.167 & 0.205 \\
\hline
\end{tabular}

The industry average unlevered beta was then re-leveraged by applying the financial structure of each unlisted firm according to the following formula:

$$
\beta_{l}=\beta_{u} \times[1+(1-t) \times D / E]
$$

The study incorporates the tax rate ( $t$ in the previous formulas) provided for by the legislation in force year by year in each country. Therefore, the tax rate applied by each company was not considered.

Firms with a negative beta were excluded from the two representative samples of listed and unlisted companies. Such a value shows that the expected return/cost of equity is lower than the risk-free rate, thus contravening the nature of the latter as a cut-off rate in the CAPM and in general in the context of investment decisions. Given that some of the assumptions in this risk pricing model concern the rationality of investors and being risk-averse, it is reasonable to assume that investors will tend to optimize their exposure to risk through appropriate portfolio diversification strategies by accepting additional risks only if the expected return is higher than the risk-free rate.

- The market risk premium was quantified starting from the values indicated by Fernandez in the surveys referring to the years 2015, 2016, and 2017 for the various European countries. These values were assigned a weighting factor (corresponding to the ratio between the market capitalization of the individual country in the Fernandez survey and the overall capitalization of the European market) obtaining a weighted market premium risk (Tables 3, 4, 5).

Table 3. MRP 2015

\begin{tabular}{lrrr}
\hline Country & $\begin{array}{r}\text { Weight (according to market } \\
\text { capitalization) } \\
(\mathrm{a})\end{array}$ & $\begin{array}{r}\text { MRP 2015 (Fernandez) } \\
\text { (b) }\end{array}$ & $\begin{array}{r}\text { Weighted } \\
\text { MRP 2015 } \\
(\mathrm{c}=\mathrm{a} \text { *b) }\end{array}$ \\
\hline Austria & $0.85 \%$ & $5.70 \%$ & $0.05 \%$ \\
Belgium & $3.04 \%$ & $5.50 \%$ & $0.17 \%$ \\
Denmark & $3.36 \%$ & $5.50 \%$ & $0.18 \%$ \\
Finland & $2.10 \%$ & $5.70 \%$ & $0.12 \%$ \\
France & $21.31 \%$ & $5.60 \%$ & $1.19 \%$ \\
Germany & $15.53 \%$ & $5.30 \%$ & $0.82 \%$ \\
Greece & $0.37 \%$ & $14.30 \%$ & $0.05 \%$ \\
Ireland & $6.59 \%$ & $5.50 \%$ & $0.36 \%$ \\
Italy & $3.83 \%$ & $5.40 \%$ & $0.21 \%$ \\
Netherlands & $7.42 \%$ & $5.90 \%$ & $0.44 \%$ \\
Poland & $0.88 \%$ & $5.20 \%$ & $0.05 \%$ \\
Portugal & $0.52 \%$ & $5.70 \%$ & $0.03 \%$ \\
Great Britain & $23.09 \%$ & $5.20 \%$ & $1.20 \%$ \\
Czech Republic & $0.16 \%$ & $5.60 \%$ & $0.01 \%$ \\
Spain & $5.68 \%$ & $5.90 \%$ & $0.34 \%$ \\
Sweden & $5.12 \%$ & $5.40 \%$ & $0.28 \%$ \\
Hungary & $0.16 \%$ & $8.80 \%$ & $0.01 \%$ \\
\hline Total & $100.00 \%$ & & $5.51 \%$ \\
\hline
\end{tabular}


Table 4. MRP 2016

\begin{tabular}{lrrr}
\hline Country & $\begin{array}{r}\text { Weight (according to market } \\
\text { capitalization) } \\
(\mathrm{a})\end{array}$ & $\begin{array}{r}\text { MRP 2016 } \\
\text { (Fernandez) } \\
(\mathrm{b})\end{array}$ & $\begin{array}{r}\text { Weighted } \\
\text { MRP 2016 } \\
(\mathrm{c}=\mathrm{a} * \mathrm{~b})\end{array}$ \\
\hline Austria & $1.08 \%$ & $5.40 \%$ & $0.06 \%$ \\
Belgium & $3.86 \%$ & $5.60 \%$ & $0.22 \%$ \\
Bulgaria & $0.18 \%$ & $8.20 \%$ & $0.01 \%$ \\
Croatia & $0.18 \%$ & $7.50 \%$ & $0.01 \%$ \\
Denmark & $4.28 \%$ & $5.30 \%$ & $0.23 \%$ \\
Finland & $2.67 \%$ & $5.15 \%$ \\
France & $27.12 \%$ & $1.57 \%$ \\
Germany & $19.76 \%$ & $1.05 \%$ \\
Greece & $0.47 \%$ & $5.80 \%$ & $0.06 \%$ \\
Ireland & $8.39 \%$ & $5.30 \%$ & $0.55 \%$ \\
Italy & $4.88 \%$ & $13.00 \%$ & $0.27 \%$ \\
Luxembourg & $1.42 \%$ & $6.60 \%$ & $0.07 \%$ \\
Malta & $0.07 \%$ & $5.60 \%$ & $0.00 \%$ \\
Netherlands & $9.44 \%$ & $4.70 \%$ & $0.48 \%$ \\
Poland & $1.13 \%$ & $6.80 \%$ & $0.07 \%$ \\
Portugal & $0.66 \%$ & $5.10 \%$ & $0.05 \%$ \\
Czech Republic & $0.21 \%$ & $6.20 \%$ & $0.01 \%$ \\
Romania & $0.21 \%$ & $7.90 \%$ & $0.02 \%$ \\
Slovenia & $0.06 \%$ & $6.30 \%$ & $0.00 \%$ \\
Spain & $7.23 \%$ & $7.40 \%$ & $0.45 \%$ \\
Sweden & $6.51 \%$ & $7.10 \%$ & $0.34 \%$ \\
Hungary & $0.20 \%$ & $6.20 \%$ & $5.02 \%$ \\
\hline Total & $100.00 \%$ & $5.20 \%$ & $5.70 \%$ \\
\hline
\end{tabular}

Table 5. MRP 2017

\begin{tabular}{lrrr}
\hline Country & $\begin{array}{r}\text { Weight (according to market } \\
\text { capitalization) } \\
(\mathrm{a})\end{array}$ & $\begin{array}{r}\text { MRP 2017 } \\
\text { (Fernandez) } \\
(\mathrm{b})\end{array}$ & $\begin{array}{r}\text { Weighted } \\
\text { MRP 2017 } \\
(\mathrm{c}=\mathrm{a} \text { *b) }\end{array}$ \\
\hline Austria & $0.85 \%$ & $6.40 \%$ & $0.05 \%$ \\
Belgium & $3.04 \%$ & $6.40 \%$ & $0.19 \%$ \\
Denmark & $3.36 \%$ & $6.10 \%$ & $0.21 \%$ \\
Finland & $2.10 \%$ & $5.90 \%$ & $0.12 \%$ \\
France & $21.31 \%$ & $6.50 \%$ & $1.39 \%$ \\
Germany & $15.53 \%$ & $5.70 \%$ & $0.89 \%$ \\
Greece & $0.37 \%$ & $16.20 \%$ & $0.06 \%$ \\
Ireland & $6.59 \%$ & $6.70 \%$ & $0.44 \%$ \\
Italy & $3.83 \%$ & $6.40 \%$ & $0.25 \%$ \\
Netherlands & $7.42 \%$ & $6.00 \%$ & $0.44 \%$ \\
Poland & $0.88 \%$ & $6.40 \%$ & $0.06 \%$ \\
Portugal & $0.52 \%$ & $7.60 \%$ & $0.04 \%$ \\
Great Britain & $23.09 \%$ & $5.90 \%$ & $1.36 \%$ \\
Czech Republic & $0.16 \%$ & $6.20 \%$ & $0.01 \%$ \\
Spain & $5.68 \%$ & $6.60 \%$ & $0.37 \%$ \\
Sweden & $5.12 \%$ & $6.80 \%$ & $0.35 \%$ \\
Hungary & $0.16 \%$ & $8.40 \%$ & $0.01 \%$ \\
\hline Total & $100.00 \%$ & & $6.24 \%$ \\
\hline
\end{tabular}




\section{Results}

\subsection{Gap Analysis of the Profitability (ROE) of Listed and Unlisted Companies}

ROE presents the following descriptive statistics (Table 6):

Table 6. Listed vs unlisted ROE: descriptive statistics table 2015-2017

\begin{tabular}{|c|c|c|c|}
\hline ROE & 2015 & 2016 & 2017 \\
\hline \multicolumn{4}{|c|}{ Sample: listed companies } \\
\hline Mean & 4.172 & 7.075 & 1.770 \\
\hline Median & 3.302 & 7.307 & 4.720 \\
\hline Std. Deviation & 4.269 & 5.258 & 7.996 \\
\hline Variance & 18.221 & 27.643 & 63.930 \\
\hline Skewness & 0.245 & -0.524 & -0.818 \\
\hline Kurtosis & -0.743 & 1.145 & -0.359 \\
\hline Minimum & -1.748 & -3.729 & -15.112 \\
\hline Maximum & 11.375 & 15.820 & 10.612 \\
\hline \multicolumn{4}{|c|}{ Sample: unlisted companies } \\
\hline Mean & 9.361 & 8.859 & 10.529 \\
\hline Median & 7.013 & 6.675 & 8.486 \\
\hline Std. Deviation & 13.719 & 12.526 & 13.357 \\
\hline Variance & 188.219 & 156.903 & 178.416 \\
\hline Skewness & 0.442 & 0.436 & 0.458 \\
\hline Kurtosis & 0.134 & 0.174 & 0.175 \\
\hline Minimum & -28.207 & -25.054 & -26.379 \\
\hline Maximum & 50.507 & 46.816 & 52.463 \\
\hline
\end{tabular}

For the year 2015, the ROE of listed companies oscillates between a minimum value of $-1.75 \%$ and a maximum value of $+11.38 \%$ with an average of $+4.17 \%$. There is the presence of positive asymmetry with a tail on the right, as evidenced by the values of the position indicators (mean> median). The descriptive statistics show a platykurtic distribution, more flattened than a normal distribution. The range of fluctuation of the ROE in 2016 is delimited by the extremes $-3.73 \%$ (lower extreme) and $+15.82 \%$ (upper extreme). The distribution presents negative asymmetry (mean <median) and is represented by a leptokurtic curve, with a more elongated than normal shape. Finally, for 2017, the descriptive statistics highlight the presence of negative asymmetry as evidenced by the value of the median above the average. From the interpretation of the kurtosis index, a platykurtic type curve is found (lower, therefore, than the normal variable). ROE has a minimum value of $-15.11 \%$ and a maximum of $+10.61 \%$.

For the sample of unlisted companies a wider range of fluctuations in ROE and greater variability of the data was noticed. This is evidenced by the values of the standard deviation and variance which appear to be significantly higher than those found in the sample of listed companies.

For the year 2015, the ROE of unlisted firms moves between a minimum of $-28.21 \%$ and a maximum of $+50.51 \%$ and presents positive asymmetry. The value of the kurtosis denotes a leptokurtic form, i.e. more pointed than the normal curve. The positive asymmetry also persists in 2016 and 2017 given the value of the average above the median. The leptokurtic form is also confirmed. In 2016, the ROE varied in a range of extremes $-25.05 \%$ and $+46.82 \%$ assuming an average value of $8.86 \%$. Finally, for 2017 the range of fluctuation is between a minimum value of $-26.38 \%$ and a maximum value of $+52.46 \%$.

The differences between the means are then calculated, verifying their statistical significance by t-test. The results are highlighted in Table 7:

Table 7. ROE differences between the means - listed vs unlisted (2015-2017)

\begin{tabular}{lrrr}
\hline & 2015 & 2016 & 2017 \\
\hline ROE & $-5.19^{* * *}$ & -1.78 & $-8.76^{* * * *}$ \\
p-value & 0.001 & 0.213 & 0.001 \\
\hline
\end{tabular}

Note. Significance level at $* 10 \%, * * 5 \%, * * * 1 \%$.

Results reported in the table show that there are statistically significant differences between listed and unlisted companies in terms of profitability. 
For the year 2015, we found a negative difference which states that the sample of listed companies has on average lower ROE values than comparable unlisted firms. This difference between the means was significant for $p=0.001$. This means that there is a probability of less than $1 \%$ that the difference in profitability between listed and unlisted companies is due to chance. For the year 2016, the difference between the averages is not significant, given the $\mathrm{p}$-value $=0.213$. Finally, for 2017 the t-test showed that the difference between the means was significant at the $1 \%$ level ( $\mathrm{p}$-value $=0.001$ ). A negative difference emerges due to the higher profitability of the sample of unlisted companies.

Results from empirical analysis highlight that listed firms have lower profitability than unlisted companies.

\subsection{Gap Analysis of the Cost of Equity (ke) of Listed Companies and Unlisted Companies}

Cost of equity shows the following descriptive statistics (Table 8):

Table 8. Descriptive statistics $k_{\mathrm{e}}(2015-2017)$

\begin{tabular}{lccc}
\hline $\mathrm{k}_{\mathrm{e}}$ & 2015 & 2016 & 2017 \\
\hline Sample: listed companies & & & 3.867 \\
Mean & 4.192 & 3.403 & 3.897 \\
Median & 3.549 & 2.402 & 2.532 \\
Std. Deviation & 2.123 & 2.178 & 6.414 \\
Variance & 4.507 & 4.744 & 0.294 \\
Skewness & 0.589 & 0.817 & -1.464 \\
Kurtosis & -0.909 & -0.489 & 0.939 \\
Minimum & 1.503 & 1.227 & 7.839 \\
Maximum & 7.910 & 7.995 & 4.403 \\
Sample: unlisted companies & & & 3.763 \\
Mean & 5.477 & 3.982 & 2.242 \\
Median & 4.760 & 3.530 & 5.025 \\
Std. Deviation & 2.521 & 1.710 & 0.570 \\
Variance & 6.353 & 2.924 & 1.906 \\
Skewness & 1.133 & 1.078 & 11.526 \\
Kurtosis & 0.610 & 0.461 & 2.080 \\
Minimum & 2.720 & 9.380 & \\
Maximum & 13.420 & & \\
\hline
\end{tabular}

In 2015 the cost of equity in listed companies varied between a minimum of $1.50 \%$ and a maximum of $7.91 \%$ recording an average value of $4.19 \%$. The distribution of the data is characterized by positive asymmetry given the value of the mean higher than the median. The kurtosis index assumes a negative value, so the data series is of the platykurtic type, with a more flattened shape than the normal distribution. The platykurtic form also characterizes the distributions in 2016 and 2017 given the negative value of kurtosis. The positive asymmetry also remains, more contained in 2017: for this year, the average value shows a smaller deviation from the median, more closely approximating a normal distribution. The range of fluctuation of the cost of equity for 2016 is bounded by $1.23 \%$ and $7.99 \%$ respectively as lower and upper extremes. In 2017, a wider range of fluctuations of values between a minimum of $0.94 \%$ and a maximum of $7.84 \%$ is observed. In the three years, there is a low variability of the data for the average value, as evidenced by the standard deviation.

In the sample of unlisted firms, an average value of $5.48 \%$ is observed for 2015 . The range of fluctuation of the values has the lower extreme $2.72 \%$ and the upper extreme $13.42 \%$. The distribution of the data shows positive asymmetry and leptokurtic form. For 2016, the cost of equity of unlisted companies ranges between a minimum of $2.08 \%$ and a maximum of $9.38 \%$. Data have positive asymmetry, which appears to be rather limited given that the mean and the median present a minimum deviation. The leptokurtic form is confirmed. Finally, for 2017 the data still show positive asymmetry and leptokurtic. The range is delimited by a lower extreme corresponding to a cost of equity of $1.91 \%$ and an upper extreme of $11.53 \%$.

The differences between the means are then calculated, verifying their statistical significance using the t-test (Table 9). 
Table 9. Differences between the means - listed vs unlisted (2015-2017)

\begin{tabular}{lccr}
\hline & 2015 & 2016 & 2017 \\
\hline ke & $-1.28^{* *}$ & -0.580 & $-0.530^{* *}$ \\
p-value & 0.040 & 0.321 & 0.037 \\
\hline
\end{tabular}

Note. Significance level at $* 10 \%, * * 5 \%, * * * 1 \%$.

The table indicates statistically significant differences in the cost of equity between listed and unlisted companies.

In 2015 results show the existence of a difference in the means between the cost of equity of listed and unlisted companies; it is negative for $1.28 \%$, because unlisted companies have on average a higher cost of capital value compared to listed firms. This is justified by the fact that the listing produces an improvement in the credit standing for companies accessing the financial market with consequent lower interest rates and, therefore, a lower cost of capital. T-test points out that the difference in the averages is significant for $p=0.040$, highlighting the existence of a probability of less than 5\% that the difference in terms of the cost of equity between listed and unlisted companies is due to chance. For the year 2016, the difference between the means is not significant given the p-value of 0.321 . For 2017 the difference, negative for $0.53 \%$, is significant at the level of $5 \%$.

In summary, this part of the analysis shows that listed firms have a lower cost of equity if compared with unlisted ones.

\subsection{Gap Analysis of the Value (ROE- $k_{e}$ ) of Listed and Unlisted Companies}

As mentioned above we intended the ROE- $\mathrm{k}_{\mathrm{e}}$ as a measure of value for shareholders; its descriptive statistics are shown below (Table 10):

Table 10. Descriptive statistics ROE- $\mathrm{k}_{\mathrm{e}}(2015-2017)$

\begin{tabular}{|c|c|c|c|}
\hline ROE-k $_{\mathrm{e}}$ & 2015 & 2016 & 2017 \\
\hline \multicolumn{4}{|c|}{ Sample: listed companies } \\
\hline Mean & -0.020 & 3.672 & -2.096 \\
\hline Median & 0.770 & 4.509 & 1.734 \\
\hline Variance & 29.225 & 23.263 & 65.920 \\
\hline Std. Deviation & 5.406 & 4.823 & 8.119 \\
\hline Skewness & -0.529 & -0.710 & -0.888 \\
\hline Kurtosis & -0.456 & 0.214 & -0.830 \\
\hline Minimum & -9.627 & -6.131 & -16.539 \\
\hline Maximum & 7.698 & 11.164 & 5.604 \\
\hline \multicolumn{4}{|c|}{ Sample: unlisted companies } \\
\hline Mean & 3.884 & 4.877 & 6.126 \\
\hline Median & 2.070 & 3.260 & 4.567 \\
\hline Std. Deviation & 130446 & 12.306 & 13.020 \\
\hline Variance & 180.796 & 151.433 & 169.521 \\
\hline Skewness & 0.250 & 0.284 & 0.286 \\
\hline Kurtosis & 0.100 & 0.146 & 0.162 \\
\hline Minimum & -31.510 & -28.090 & -28.958 \\
\hline Maximum & 40.470 & 38.660 & 42.365 \\
\hline
\end{tabular}

The listed companies show an average negative ROE- $\mathrm{k}_{\mathrm{e}}$ of $0.02 \%$ in 2015 . The gap between return on equity and cost of equity for this year fluctuates from a minimum of $-9.63 \%$ to a maximum of $7.70 \%$. Data show negative asymmetry and the distribution is represented by a platykurtic curve as evidenced by negative kurtosis. For 2016, the range of fluctuation of the differential values is wider, with the lower extreme $-6.13 \%$ and the upper extreme $11.16 \%$. The average ROE- $\mathrm{k}_{\mathrm{e}}$ value for that year was $3.67 \%$. The distribution of the data is characterized by negative asymmetry and leptokurtic. For 2017, the ROE- $\mathrm{k}_{\mathrm{e}}$ assumes a minimum value of $-16.54 \%$ and a maximum value of $5.60 \%$ with an average value of $-2.10 \%$. The negative asymmetry remains and a platykurtic form is observed.

For the sample of unlisted companies, in 2015 the ROE- $\mathrm{k}_{\mathrm{e}}$ recorded a minimum value of $-31.51 \%$ and a maximum of $40.47 \%$. The data show positive asymmetry given the value of the mean higher than that of the median and leptokurtic form. For 2016, an average differential of $4.88 \%$ is observed. The range of fluctuation of 
the values is delimited by the lower extreme $-28.09 \%$ and the upper extreme $38.66 \%$. The positive asymmetry and the leptokurtic form are confirmed. For 2017, the positive asymmetry and the leptokurtic form remain, given the value found for the kurtosis index. The average ROE- $\mathrm{k}_{\mathrm{e}}$ is equal to $6.13 \%$ with fluctuations between a minimum of $-28.96 \%$ and a maximum of $42.36 \%$. Greater dispersion of the data is observed as evidenced by the value of the standard deviation and variance higher than the sample made up of listed companies.

The result of the statistical test is summarized below (Table 11):

Table 11. ROE- $\mathrm{k}_{\mathrm{e}}$ differences between the means - listed vs unlisted (2015-2017)

\begin{tabular}{lrrr}
\hline & 2015 & 2016 & 2017 \\
\hline ROE- $\mathrm{k}_{\mathrm{e}}$ & $-3.90^{* *}$ & -1.210 & $-8.220^{* * *}$ \\
p-value & 0.031 & 0.355 & 0.002 \\
\hline
\end{tabular}

Significance level at $* 10 \%, * * 5 \%, * * * 1 \%$.

In 2015 for ROE- $\mathrm{k}_{\mathrm{e}}$ there is a negative difference between the means of $3.90 \%$. The statistical test shows that this difference is significant for $\mathrm{p}=0.031$. This means that there is a probability of less than $5 \%$ that the difference in value between listed and unlisted companies is due to chance. For 2016, the test returns the non-significance of the difference between the means. Finally, for the year 2017, the t-test showed that the difference between the means is significant at the level of $1 \%$, detecting a negative difference in the averages.

\section{Conclusions}

When a company has to face business growth needs, reliance on financial markets can be the most appropriate solution. Corporate growth constitutes a strategy that requires equity, i.e. capital destined to finance long-term investments. This study aimed to investigate the listing to create or destroy value for shareholders. The adopted approach is independent of financial performance, widely debated in the relevant literature, and uses the ROE- $\mathrm{k}_{\mathrm{e}}$ differential as an explanatory measure of the shareholder value. The analysis involved listed and unlisted energy firms, located in the countries that contribute to the Stoxx Europe 600 index. Three aspects are considered: profitability, cost of equity, and value. The evidence shows that the listing has a positive impact on the cost of capital: for listed companies the cost of equity is on average lower when compared with the average for the sample of unlisted companies. On the other hand, access to the market would seem to harm profitability and the creation of value highlighting the existence of significant differences in favor of unlisted companies. So, from the study, it emerges, therefore, that in the Energy sector the listing destroys value. The results, which highlight the superiority of unlisted, are in line with the findings of other studies such as that of Nguyen Van Tan and Trinh Quoc Trung (2019), Akguc, Choi and Kim (2015), Xiaoying Xie (2010), Rondi et al (1994). This study has several limitations attributable among other things to the consideration of a relatively short period. Future developments of this work may overcome some limitations by extending the reference time horizon and using additional variables such as governance, financial structure, operations in the renewable energy sector, size.

\section{References}

Abbate, C., \& Sapio A. (2015). Gazelles in the City: Stock Market Listing and its Impact on Firm Growth Quantiles. $56^{\text {th }}$ Annual conference, University of Naples Parthenope

Adams, M., \& Thornton, B. (2009). A Comparison of Alternative Approaches to Equity Valuation of Privately Held Entrepreneurial Firms.

Aiello, F., \& Silipo, D. (1997). Gli effetti del mercato dei capitali sulla performance delle imprese italiane. Quaderni di Economia e Finanza, 6(2), 83-113.

Akguc, S., Choi, J., \& Kim, S. (2015). Do private firms perform better than public firms? Working paper, Temple University, Philadelphia.

Arzac, E. R. (1986). Do Your Business Units Create Shareholder Value. Harvard Business Review.

Balafas, N., \& Florackis, C. (2014). CEO Compensation and Future Shareholder Returns: Evidence from the London Stock Exchange. Journal of Empirical Finance, 27, 97-115. https://doi.org/10.1016/j.jempfin.2013.10.011

Bates, J., \& Hally, D. L. (1982). The Financing of Small Business (3rd ed.). London, Sweet \& Maxwell.

Berkovitch, E., Gesser, R., \& Sarig, O. H. (2004). To Be (Public) or Not to Be (Public): A New Test. 
https://doi.org/10.2139/ssrn.567107

Capasso, A., Rossi, M., \& Simonetti, B. (2005). Ownership Structure Heterogeneity and Performance: A Comparison between Listed and Unlisted Companies. https://doi.org/10.2139/ssrn.890624

Carpenter, R. E., \& Rondi, L. (2006). Going Public to Grow? Evidence from a Panel of Italian Firms. Ceris-Cnr Working Paper. https://doi.org/10.1007/s11187-005-4323-3

Caselli, S. (2003). PMI e sistema finanziario. Comportamento delle imprese e strategia delle banche, Egea

Chen, L., \& Qiao, Z. (2008). Improvement of Eva on traditional performance measurement: An application of neural network. In 2008 Fourth international conference on natural computation, 2, 424-428. https://doi.org/10.1109/ICNC.2008.52

Corigliano, R. (2001). Il venture capital. Finanziamento dell'innovazione, capitale di rischio e nuovi mercati finanziari. Bancaria Editrice.

Damodaran, A. (2012). Investment valuation: Tools and techniques for determining the value of any asset. Wiley Finance Series.

Fama, E. F., \& Miller, M. H. (1972). The theory of finance. Dryden Press.

Fernandez, P. (2007). Valuing Companies by Cash Flow Discounting: Ten Methods and Nine Theories. IESE Business School, Madrid, Spain. https://doi.org/10.1108/03074350710823827

Fernandez, P. (2019). WACC and CAPM according to Utilities Regulators: Confusions, Errors, and Inconsistencies. https://doi.org/10.2139/ssrn.3327206

Graham, B. (1954). The Intelligent Investor K-E. Harper, New York.

Greenwald, B. C. N., Van Biema, M., Kahn, J., \& Sonkin, P. D. (2001). Value Investing: From Graham to Buffett and Beyond. John Wiley \& Sons Inc.

Guiso, A. (2003). Small business finance in Italy. EIB Papers-European Investment Bank, Economics Department, 8.

Henry, O. T. (2008). Econometric advice and beta estimation. Australian Energy Regulator. Retrieved from https://www.aer.gov.au/system/files/Attachment\%20C\%20-\%20Henry\%20-\%20Econometic\%20advice\%20 and\%20beta\%20estimation_0.pdf

Henry, O. T. (2009). Estimating $\beta$. Australian Energy Regulator. Retrieved from http://www.aer.gov.au/sites/default/files/Attachment\%20C\%20-\%20Henry\%20-\%20Estimating\%20beta.pdf

Henry, O. T., \& Street, C. (2014). Estimating $\beta$ : An update. Australian Energy Regulator. Retrieved from https://www.aer.gov.au/system/files/Henry\%20\%E2\%80\%93\%20\%20Estimating\%20Beta\%20\%E2\%80\%9 3\%20An\%20update\%20\%E2\%80\%93\%20April\%202014_0.PDF

Hong, Vo, D., \& Pham, T. N. (2017). Systematic Risk in Energy Businesses: Empirical Evidence for the ASEAN. International Journal of Economics and Financial Issues, Econjournals, 7(1), 553-565.

Hung, D. N., Thien, N. D., \& Liem, N. T. (2017). The impact of equitization on firm performance: The case of Vietnam. International Research Journal of Finance and Economics, 12(164), 68-74.

Hutchinson, P. J., \& Ray, G. H. (1983). The Financing and Financial Control of Small Enterprise Development. Gower Publishing Company Limited, England.

Jensen, M. C., \& Meckling, W. H. (1976). Theory of the firm: Managerial behavior, agency costs and ownership structure. Journal of Financial Economics, 3(4), 305-360. https://doi.org/10.1016/0304-405X(76)90026-X

Juan García-Teruel, P., \& Martínez Solano, P. (2007). Effects of Working Capital Management on SME Profitability. International Journal of Managerial Finance, 3(2), 164-177. https://doi.org/10.1108/17439130710738718

Jun, S. G., \& Jen, F. C. (2003). Trade-Off Model of Debt Maturity Structure. Review of Quantitative Finance and Accounting, 20, 5-34. https://doi.org/10.1023/A:1022190205033

Keown, A. J., Scott, J. R. D. F., Martin, J. D., \& Petty, J. W. (1985). Basic Financial Management (3rd ed.) Prentice-Hall International Editions, New Jersey.

Kersan-Škabić, I. (2019). The drivers of global value chain (GVC) participation in EU member states. Economic Research-Ekonomska Istraživanja, 32(1). https://doi.org/10.1080/1331677X.2019.1629978 
Lafont, J., Romero, J., Palacios, M., \& Ruiz, F. (2020). Shareholder return and value creation at listed infrastructure companies in different economic contexts. Economic Research-Ekonomska Istraživanja, 1-16. https://doi.org/10.1080/1331677X.2020.1860801

Lan, Y., \& Li, S. (2005). The correlation between company value and short-term earnings: evidence from listed companies in electrocommunication industry of China. Journal of System Science \& Information.

Leland, H., \& Pyle, D. H. (1977). Informational Asymmetries, Financial Structure, and Financial Intermediation. Journal of Finance, 32(2), 371-387. https://doi.org/10.2307/2326770

Magni, C. A. (2011). ROE, Market Value Added and shareholder value creation, $34^{\text {th }}$ Annual Congress of the European Accounting Association (EAA). Rome, 20-22 April 2011 with the title "Return On Equity, Internal rate of Return and shareholder value creation.

Mayer, C., \& Alexander, I. (1991). Stock Markets and Corporate Performance: A Comparison of Quoted and Unquoted Companies. CEPR Discussion Paper. 571.

McLaney, E. (2009). Business Finance: Theory and Practice (8th ed.). Prentice Hall, United Kingdom.

Mikkelson, W. J., Partch, M. M., \& Shan, K. (1997). Ownership and operating performance of companies that go public. Journal of Financial Economics, 44(3), 281-307. https://doi.org/10.1016/S0304-405X(97)00006-8

Mitra, A., O'Regan, N., \& Sarpong, D. (2018). Cloud resource adaptation: A resource-based perspective on value creation for corporate growth. Technological Forecasting and Social Change, 130, 28-38. https://doi.org/10.1016/j.techfore.2017.08.012

Muthoni, K. G., Jagongo, A., \& Muniu, J. (2019). Effect of Equity Financing on Shareholder Value Creation of Non-Financial Firms Quoted at the Nairobi Securities Exchange. Journal of Finance \& Accounting, 3(5), $32-52$.

Myers, S. C. (1977). Determinants of Corporate Borrowing. Journal of Financial Economics, 5, 147-175. https://doi.org/10.1016/0304-405X(77)90015-0

Myers, S. C., \& Majluf, N. S. (1984). Corporate financing and investment decisions when firms have information that investors do not have. Journal of Financial Economics, 13, 187-221. https://doi.org/10.1016/0304-405X(84)90023-0

Nhan, N. T., \& Son, T. H. (2017). Equitization and operating and financial performance: Empirical evidence from Vietnamese companies. International Research Journal of Finance and Economics, 12(164), 75-84.

Osteryoung, J. S. (1997). Small Firm Finance: An Entrepreneurial Analysis. The Dryden Press, U.S.A.

Ou, C., \& Haynes, G. W. (2006). Acquisition of Additional Equity Capital by Small Firms - Findings from the National Survey of Small Business Finances. Small Business Economics, 27, 157-168. https://doi.org/10.1007/s11187-006-0009-8

Pagano, M., Panetta, F., \& Zingales, L. (1996). Why Do Companies Go Public? An Empirical Analysis. The Journal of Finance, 53(1), 27-64. https://doi.org/10.1111/0022-1082.25448

Rijken, H. A., Booij, M. C., \& Buckley, A. (1999). Valuation Differences between Listed and unlisted Companies - Empirical Evidence from the UK. The European Journal of Finance, 5, 256-275. https://doi.org/10.1080/135184799337091

Rodriguez-Fernandez, M. (2016). Social Responsibility and Financial Performance: The Role of Good Corporate Governance. BRQ Business Research Quarterly, 12(2), 137-151. https://doi.org/10.1016/j.brq.2015.08.001

Rondi, L., Sembenelli, A., \& Zanetti, G. (1994). Is Excess Sensitivity of Investment to Financial Factors Constant across Firms? Evidence from Panel Data on Italian Companies. Journal of Empirical Finance, 1, 365-383. https://doi.org/10.1016/0927-5398(94)90009-4

Ross, S. A. (1977). The Determination of Financial Structure: The Incentive-Signalling Approach. Bell Journal of Economics, 8(1), 23-40. https://doi.org/10.2307/3003485

Schoubben, F., \& Van Hullen, C. (2008). The Impact of Growth Opportunities on the Investment-Cash Flow Sensitivity. Department Of Accountancy, Finance And Insurance (Afi). https://doi.org/10.2139/ssrn.1101685

Skinner, D. J., \& Sloan, R. G. (2002). Earnings surprises, growth expectations, and stock return or don't let an earnings torpedo sink your portfolio. Review of Accounting Studies, 7(2-3), 289-312. https://doi.org/10.1023/A:1020294523516 
Stern, J. M., Stewart, G. B., \& Chew, D. H. (1995). The Eva® Financial Management System. Journal of Applied Corporate Finance, 8(2). https://doi.org/10.1111/j.1745-6622.1995.tb00285.x

Tiozo, E., \& Leismann, E. L. (2019). Análise De Risco Das Empresas Listadas no Ise 2018 Da B3. Reunir: Revista De Administração Contabilidade E Sustentabilidade, 9(1), 27-40. https://doi.org/10.18696/reunir.v9i1.814

Van Tan, N., \& Quoc Trung, T. (2019). Listing and Firm Performance in a Transition Economy. Asian Economic and Financial Review, 9(3), 353-365. https://doi.org/10.18488/journal.aefr.2019.93.353.365

Whitney, J. O., \& Deming, W., E. (1996). The Economics of Trust: Liberating profits and restoring corporate vitality. New York: Mc Graw- Hill.

Worthington, A. (2013). Small and Medium-Sized Enterprises Financing: A Review of Literature. International Journal of Business and Management, 8(14), 36-54. https://doi.org/10.5539/ijbm.v8n14p36

Xie, X. (2010). Are publicly held firms less efficient? Evidence from the US property-liability insurance industry. Journal of Banking \& Finance, 34(7), 1549-1563. https://doi.org/10.1016/j.jbankfin.2010.01.007

\section{Copyrights}

Copyright for this article is retained by the author(s), with first publication rights granted to the journal.

This is an open-access article distributed under the terms and conditions of the Creative Commons Attribution license (http://creativecommons.org/licenses/by/4.0/). 